UDC 373.5.011.3-051:94]:004.77

DOI 10.31494/2412-9208-2020-1-2-60-69

\title{
PROPHYLACTIC COMPETENCES OF TEACHERS-TUTORS
}

ПРОФІЛАКТИЧНІ КОМПЕТЕНЦІЇ ВЧИТЕЛІВ-РЕПЕТИТОРІВ

\author{
Slawomir SLIWA \\ Славомір СлИВА \\ s.sliwa@poczta.wszia.opole.pl \\ https://orcid.org/0000-0003-0465-0644 \\ The Academy of Management and \\ Академія управління та \\ Administration \\ Opole, Poland \\ адміністрування \\ Original manuscript received: June 04, 2020 \\ Revised manuscript accepted: August 15, 2020
}

\begin{abstract}
The aim of this article was to show the importance of competence in prophylaxis work of a teacher-educator.

In the introduction to this article they were presented categories of professional competence of teachers. In the following section author discuss about the competencies they should have a teacher-educator and teacher-person who deals with prophylaxis.

Given the assumptions of the modern model of prophylaxis, where the main executors of prophylaxis are primarily teachers, author show that competence in the field of knowledge and skills should be a teacher implementing school prophylaxis program. Despite the lack of standardized learning outcomes for teachers in the field of prophylaxis in the article suggested areas, in which the author's opinion, should be trained by teachers.

Prophylaxis, which is carried out primarily at school, and one of its tasks is to support the education process should be carried out by professionals who should also have in addition to knowledge and skills in the field of competence of personality that predispose them to work with children and youth.
\end{abstract}

Keywords: competence of teachers, competence prophylaxis, prophylaxis, school prophylaxis program

\section{Introduction}

A modern teacher should be wise, versatile, talented, should provide knowledge and experience, be competent and constantly improve his professional skills. It should also be remembered that the teacher is a man, friend: forgiving, supportive and understanding the problems of others, and students very often love teachers not for what they have taught them, but for who they were. [15, s. 20].

$\mathrm{He}$ is a man who should have enormous knowledge, possess a wide range of skills and social competences. The teaching profession requires continuous education or self-education and constant improvement of ones competencies.

Teachers' professional development is an extremely complex process, it requires effort and a focus on introducing changes. Its scope is not only limited to the professional, but also in the personal sphere [27, s. 77]. 
A modern teacher should also strive to constantly improve their competences. As Agnieszka Cybal-Michalska emphasizes in the context of the development of career competences, it should be understood as a process of acquiring new skills by the subject and improving of those already possessed. [2, s. 107].

Zbyszko Melosik notices that "regardless of the achievements of modern pedagogical thought emphasizing the idea of empowering students in the education process, in practice the main criteria for assessing the work of school principals is directly related to the results of teaching, obtained primarily in the knowledge and competence tests. There is a clear preference for the educational / teaching function at the expense of the school's caring and educational function " [16, s. 132].

When discussing teacher competences, three groups are most often distinguished [25, s. 175]:

- substantive competence related to the subject being taught - the teacher is an expert and subject adviser;

- didactic and methodological competences - they refer to the teacher and student workshop, i.e. methods and techniques of teaching and learning, especially activating, design and group work; the teacher is a teaching advisor,

- educational competences - these are different ways of influencing students; these include communication and networking skills, solving problems of a given developmental age, etc.

Maria Czerepaniak-Walczak distinguishes four categories of competences: output, mature, changeable and core. Initial competences, according to the author, do not necessarily have to be related to a specific profession, although they constitute the foundation for performing professional tasks and determine the direction of education and improvement. They require constant development and updating. The category of mature competences are those that play an important role in fulfilling current professional tasks. However, they should be supplemented with competences for change, which is distinguished by openness to newness, as well as openness to solve any problems accompanying the implementation of professional tasks. The last category, core competences, also called emotional competences, are all the dispositions that play a significant role not only at a given stage of the implementation of professional tasks, but also in the future. Their distinguishing feature is openness to everything new, but also a continuation of what corresponds with the content of these changes [3, s. 90].

Robert Kwaśnica divides competences into practical-moral and technical: [12, s. 300-301]:

- Practical and moral competences, including: interpretative competences - this kind of competence allows us to see the world as a reality that requires constant interpretation, and constantly revealing its sense; these competences make it possible to ask questions that makes understanding the world an endless task; moral competence - it's the ability to conduct moral reflection, not just knowledge of moral norms and orders; these competences 
are contained in questions about the morality of our behavior; communication competence - the ability to be in a dialogue with others and with yourself, the ability to be dialogical way of being, whereby dialogue is not understood here as just the ability to conduct discussions, but rather as a conversation that breaks the anonymity of statements and is an attempt to understand ourselves and what surrounds us.

- Technical competences, which include: postulative (normative) competences:

- understood as the ability to speak for specific goals, the ability to identify with them; they can mean imitating the goals achieved by others, but above all the choice of goals compatible with the accepted role or the ability to set individual goals;

methodological competence - it is the ability to act according to the rules that determine the optimal order of certain activities; the content of these rules is an action program telling you what and in what order you need to follow to achieve the intended goal;

implementing competences - understood as the ability to select appropriate measures and create conditions that are conducive to achieving a goal;

they are used by the teacher to develop teaching material and organize time, space and engage participants of the teaching process in a way that ensures effectiveness.

\section{Discussion and conclusions}

The contemporary model of prevention assumes that its implementers will be primarily teachers and youth leaders. First of all, teachers are required to have many competences, in particular in terms of knowledge, skills and social competences in the field of prevention. Prevention at school is designed to, among others supplement the gaps that have arisen as a result of upbringing in the family. In this way, teachers become specialists who are to support the process of development of children and youth through the implementation of school prevention programs.

As Mariusz Jędrzejko emphasizes, the low quality of school prophylaxis and health education is one of the key factors influencing the growth of risky behaviors [7, s. 22]. Therefore, along with the metamorphosis and escalation of unfavorable phenomena, modern school becomes a place to fight deviant behavior of children and youths. [8, s. 392].

Through open communication between teachers and children and youth, the teaching staff can establish a good contact with the pupils [4, p. 148]. In addition, prevention should use thematic openness, where the holistic exploration of the world is combined with the opportunity for individual and social experience of processes, phenomena and events that are taking place in it [24, p. 25].

It should be remembered that teachers, especially at the first stage of education, are also a model of pro-social behavior for children and youths. Prosocial personality is formed primarily in the environment of people behaving in a pro-social manner, including teachers who can provide authentic models of behavior [21, p. 312]. This is one of the preventive actions assumptions that should be implemented at school. 
Therefore, despite the fact that every educator should perform tasks related to the role of a teacher and educator, even in the school's perception, the role of a teacher is determined to a greater extent by his professional identity. Moreover, teachers of particular subjects primarily assess their specialist and didactic competences - in this dimension they feel professional, while it is a bit more difficult for them to find themselves in the role of transmitting certain values and influencing correct attitudes [23, p. 13]. The specificity of teaching and upbringing suggests that when talking about professional qualifications one should take into account the level of professional development of teachers which will allow to effectively manage the processes of teaching and education in the complex and dynamic conditions of school life. Therefore, according to this assumption, professional qualifications determine the preparation of teachers to perform teaching, educational and organizational activities [11, p. 73].

The professional qualifications of the teacher-educator are[11, s. 74]:

- moral attitudes and deep conviction about the need to consolidate pro-social attitudes of young people;

- physical and mental health as a potential and necessary level of mental persistence and general mental fitness;

- specialist theoretical and practical knowledge.

In turn, pedagogical qualifications mean appropriate preparation for educational work, for work in a profession that requires a deliberate and conscious educational impact on an individual or a group. These qualifications should include: pedagogical knowledge, thinking and pedagogical activity [11, s. 75].

The task of the pedagogue, teacher-tutor is to recognize the needs and problems of students, determine the functioning of students in the family, school, peer group, and then take preventive and corrective actions in the event of identified deficiencies [26, s. 125].

Bożena Muchacka emphasizes that psychosocial predispositions, such as empathy, kindness, interpersonal skills, leadership, negotiation, analysis and diagnosis skills, planning skills, time planning, space and information management, self-discipline, awareness of ethical and moral standards or cocreation of educational policy, deserve special attention. [17, s. 38] Other basic competences that should be added to the list of professional competences of every modern teacher are: specific psychological predispositions, personal culture and knowledge of savoir-vivre, i.e. forms of good education, responsibility for raising children and youth, respect for the student, recognition and even the possibility of creating a proper positive image of both: one's own and of the educational institution [18, s. 232-233].

Zbigniew B. Gaś writes that a competent teacher at school should [5, s. 11-12]: provide a constructive role model for your student; be an efficient didactic teacher, providing students with accessible and understandable contemporary scientific achievements; be an efficient trainer in teaching and improving the basic skills needed to lead a subjectively satisfying and socially constructive lifestyle; be an efficient guide in discovering personal potentials, 
implementing development tasks and shaping responsibility for own development based on a clear and socially accepted system of values.

Moreover, the teacher should be effective in the field of [6, p. 90]: the process of shaping the child's self-image; the impact of needs on the interpersonal and social functioning of the child; the impact of communication processes on avoiding dysfunction and promoting development.

The preventive teacher plays a key role in helping the student's development. A prerequisite for its effective operation is to present six personality traits and five conditions necessary to support student development in educational contact. Personality traits include: awareness of yourself and your values system, experiencing and showing feelings, performing model functions for the assisted, interest in people and social affairs, clear ethical principles and a sense of responsibility. The necessary conditions are: empathy, warmth and care, openness, positive attitude and respect for the assisted, as well as specificity [5, s. 17].

A prevention specialist should be aware that professionalism is based on high competence. Therefore, the duty of competent prophylaxis is continuous improvement of his work technique, acquiring professional knowledge and skills, the ability to apply this knowledge and skills in situations requiring immediate intervention, knowledge of preventive programs in order to select them correctly and the ability to construct or modify them in order to adapt them to the needs of a given environment or group [13, s. 390-399].

The aim of self-education here is to increase the skills of pedagogical work, to achieve higher results of professional goals or to master the research technique [20, p. 102], which is very important in the case of constructing a prevention school program.

Moreover, a preventive specialist understands the need for preventive treatments, realizes the effectiveness of his actions, their positive significance for the good of an individual, group and society, and believes in his own abilities and skills. He can also plan, implement, verify and evaluate his own preventive actions. Understands that in these activities partnership, friendship, respect, mutual help are important, as well as the involvement of parents, educators, or possibly specialists of various fields [13, s. 390-399].

Competent preventive teacher has attitudes that allow effectively influence students, their parents and other members of the school community and the environment. There are many theories and ideas for the role of the teacher in addiction prevention. It is known that positive relationships with adults, e.g. a teacher, bond with him and the school, teachers' upbringing skills, and successful learning are protective factors that are associated with the school. Therefore, it is worth making efforts to improve skills in this area.

Dorota Macander emphasizes that a preventive teacher should have the following competences [14, s. 17-22]:

- epidemiological knowledge regarding the results of research on the use of nicotine, alcohol and drugs by children and adolescents;

- knowledge of warning signals and types of psychoactive substances (primarily those that are "popular" in a given local environment); 
- knowledge of substances used by students;

- knowledge of students' development needs to adapt activities undertaken to the characteristics of the development period;

- knowledge about prevention - about concepts, strategies for researching the need for prevention, about constructing and assessing the effectiveness of prevention programs;

- ability to motivate to take preventive actions and understand their coherent combination with educational activities;

- ability to improve interpersonal competences and develop personality dispositions;

- ability to build and maintain authority;

- ability to deal with your own emotions;

- ability to positive, conscious modeling;

- the ability to show understanding and respect for the student, to give him attention.

Ireneusz Siudem among the skills of persons dealing with prevention mentions [22, s. 87]::

- ability to safely explore;

- ability to learn from trial and error;

- ability to use feedback;

- teamwork skills;

- knowledge of basic professional principles and procedures;

- ability to make contact and conclude a contract;

- ability to build a diagnosis of a person, family, group;

- ability to construct a program of individual and group interactions;

- ability to build and maintain authority;

- ability to deal with your own emotions;

- the ability to influence positively and consciously;

- ability to understand and respect.

In addition, prevention-teacher should have knowledge about the problem (epidemiological), psychological (in the field of developmental and social psychology, concerning the psychophysical development of children and adolescents, and social mechanisms affecting behavior), about preventive work methods and knowledge of law (relating to both mentees) and the specifics of preventive programs' functioning) [22, s. 88].

According to Krzysztof Ostaszewski, prevention-teacher should be aware of the progress in scientific knowledge on risky behavior of children and youth. This knowledge should include types of behavior, reasons for their occurrence and developmental functions. In addition, prevention should have knowledge about prevention in the field of: prevention in health care, prevention and upbringing, ethics in prevention, prevention based on knowledge and evidence, as well as systemic solutions and legal issues. [19, s. 9-10].

Competent prevention-teacher also has the skills to communicate well with participants in prevention activities and skills to correctly implement preventive activities [19, s. 11]. 
The last area, according to this proposal, are skills to improve the quality of one's own actions and relations with the world - it is about planning and evaluation of preventive actions. The catalog of these skills is closed by competences for cooperation and maintaining correct relations with social partners (school, non-governmental organization, local government, counseling center, scientific institution etc.) [19, s. 12].

Table 1. Areas of professional competence of prevention-teacher according to Krzysztof Ostaszewski

\begin{tabular}{|l|l|}
\hline Knowledge & $\begin{array}{l}\text { Basics of knowledge about risky behavior } \\
\text { of children and youth }\end{array}$ \\
\cline { 2 - 3 } 'Face to face' work skills & $\begin{array}{l}\text { Basics of knowledge about prevention } \\
\text { with participants of preventive activities }\end{array}$ \\
\hline & $\begin{array}{l}\text { Skills for the proper implementation of } \\
\text { preventive measures }\end{array}$ \\
\hline $\begin{array}{l}\text { Skills for the quality of work and } \\
\text { relationships with the outside world }\end{array}$ & $\begin{array}{l}\text { Skills for planning and evaluation of } \\
\text { preventive measures } \\
\text { Skills of cooperation with partners and } \\
\text { project support }\end{array}$ \\
\hline
\end{tabular}

Source: K. Ostaszewski, Kompetencje zawodowe profilaktyka, „Serwis informacyjny narkomania" nr 4 (68), 2014, s. 9. [19, s. 9]

Competent prevention-teacher should have knowledge of:

- the basics of professional prevention: the legal basics of preventive interventions, preventive interventions strategies, social science research methodology, psycho-pedagogical diagnostics, constructing preventive programs, monitoring and evaluation;

- basics of knowledge about risk behaviors of children and adolescents: protective factors and risk factors, research on risk behaviors, psychoactive substances, classification of risk behaviors of children and adolescents;

- basics of knowledge about the developmental regularities of children, adolescents and adults, and interpersonal relations: pedagogy of behavioral disorders, social, creative, caring and educational, resocialization, special pedagogy, social, developmental and clinical psychology, sociology of deviation and social control, sociology of youth ;

- the basics of knowledge about working with children, youth and parents: the scientific theoretical foundations explaining the behavior of children, adolescents and adults, forms and methods of teaching, and working with children and adolescents.

Should also have skills in:

- work with students and their parents: diagnostics, work with children and their parents, motivating others, setting an example, exerting positive influence on others, building authority, building a team, building positive relationships with others, cooperation; 
- designing preventive programs: construction and implementation of school prevention programs;

- implementation of preventive programs: monitoring and evaluation of preventive programs;

- psychosocial skills: improving competences, self-education, communication skills, coping with difficult situations, assertiveness, problem solving, creativity, coping with stress, making decisions, recognizing emotional states of one's own and others, empathy.

Table 2. Areas and scope of knowledge and skills of the prevention-teacher

\begin{tabular}{|l|l|}
\hline \multicolumn{1}{|c|}{ Area: } & \multicolumn{1}{|c|}{ Scope: } \\
\hline Knowledge & Basics of professional prevention. \\
& Basics of knowledge about risky behavior of children and \\
& youth. \\
& Basics of knowledge in the field of developmental \\
& regularities of children, adolescents and adults, as well as \\
& interpersonal relations. \\
& Basics of knowledge about working with children, youth and \\
& parents \\
\hline Skills & Work with students and their parents. \\
& Designing preventive programs. \\
& Implementing preventive programs. \\
& Psychosocial skills \\
\hline
\end{tabular}

Source: Own elaboration.

As can be seen from the above proposals regarding professional competences in the field of prophylaxis, there are many areas in which a person dealing with the profession must improve their competences. It should be noted that a competent preventive teacher is a person who not only has the appropriate education, but, perhaps even above all, appropriate emotional and interpersonal qualifications to work with children and youth. It is not enough to have the appropriate knowledge and skills. There is still a need for an appropriate approach and character traits that may determine the effectiveness of preventive interventions.

Ending. It is particularly important, as M. Kowalski emphasizes, that education towards responsibility for health should refer to stimulating, revitalizing communities or environments in order to realize responsibility for the value of health $[9$, s. 173]. Health culture is instrumental and is an element of the whole in a functional sense, it is a set of phenomena learned in the learning process: intentional and unintentional, conscious and unconscious, as well as imitation [10, s. 209]. Therefore, in advance, when preparing students for the teaching profession, work on shaping competences in the field of prevention should be undertaken.

The key features of an effective prevention program include executors' competences. They consist of theoretical knowledge about prevention and practical knowledge about running a specific program. It is also important to provide supervision, substantive and financial support to implementers. The motivation of the implementers to preventive work and constant, daily contact 
with program recipients are also of key importance. For this reason, it is recommended that preventive programs are implemented by properly prepared teachers and educators [1, s. 10].

The contemporary model of preventive interactions assumes that it is teachers who, above all, implement preventive measures. Therefore, it is important that the people who implement the school's prevention program are properly prepared for this. The standards of education preparing for the teaching profession assume the effects of education in the field of preparation for the implementation of didactic, educational or care professional tasks.

School education programs and school prevention programs operate in schools. Therefore, in educating future teachers, more attention should be paid to preparation for the implementation of preventive tasks. This may be facilitated by the preparation of appropriate standards for educating people who want to deal with prevention.

\section{Bibliography}

1. BORUCKA A, PISARSKA A, BOBROWSKI K. (2014) ABC szkolnej profilaktyki zachowań ryzykownych dzieci i młodzieży. Świat problemów. Nr 1. S. 5-11.

2. CYBAL-MICHALSKA A. (2014). Proaktywność w karierze jako narzędzie inwestycji i odnawialność kapitału kariery młodzieży akademickiej. Rocznik Pedagogiczy. Nr 37. S. 93-108.

3. Czerepaniak-Walczak M. (1997). Aspekty i źródła profesjonalnej refleksji nauczyciela: monografia. Toruń.

4. DEPTUŁA M. (1996). Nawiązanie bliskiego kontaktu z wychowankami (propozycje do badań). Studia Pedagogiczne. Nr 24. S. 147-153.

5. GAŚ Z. B. (2001). Doskonalący się nauczyciel: monografia. Lublin.

6. GAŚ Z. B. (1994). Zaburzenia w zachowaniu - przyczyny, przejawy, środki zaradcze. Wspomaganie rozwoju dziecka: monografia. Lublin. S. 71-105.

7. JĘDRZEJKO M. (2013). Młodzi ludzie w świecie wielowymiarowego ryzyka: ujęcie socjopedagogiczne. Społeczeństwo i rodzina. Nr 35. S. 8-36.

8. KANIA S. (2014). Pedagogika turystyki jako metoda w profilaktyce społecznej. Ogrody Nauk i Sztuk. Nr 4. S. 392-399.

9. KOWALSKI M. MALINOWSKI W. KOWALSKI P. (2005). Elementy prozdrowotnego stylu życia studentów kierunków nauczycielskich na tle oddziaływań edukacyjnych. Prace Naukowe Akademii im. J. Długosza w Częstochowie. Kultura Fizyczna. Nr 6, 2005. S. 171-184.

10. KOWALSKI M. (2009). Kultura zdrowotna - wymiary edukacyjne (w kierunku odpowiedzialności za zdrowie). Prace Naukowe Akademii im. J. Długosza w Częstochowie. Kultura Fizyczna. Nr 8. S. 207-216.

11. KOSYRZ Z. (1995). Osobowość wychowawcy: monografia. Warszawa.

12. KWAŚNICA R. (2003). Wprowadzenie do myślenia o nauczycielu. Pedagogika. Podręcznik akademicki. Tom 2. Warszawa. S. 291-319.

13. ŁUKAWSKA M. (2007). Kompetentny nauczyciel klas początkowych jako specjalista profilaktyk. Nauczyciel kompetentny, Teraźniejszość i przyszłość: monografia. Lublin. S. 387-393.

14. MACANDER D. (2012) Profilaktyki uzależnień w szkole - e-poradnik. Warszawa. (http:ore.edu.pl).

15. MALEC A. (2013). O przestrzeni profesjonalnych kompetencji współczesnego nauczyciela. Kompetencje zawodowe nauczycieli w teorii i praktyce: monografia. Nowy Sącz. S. 14-21. 
16. MELOSIK Z. (2014). System kształcenia i doskonalenia kadry kierowniczej w krajach Unii Europejskiej i Stanach Zjednoczonych: monografia. Warszawa.

17. MUCHACKA B. (2006). Poszukiwanie kanonu treści kształcenia nauczycieli. Kształcenie nauczycieli przyszłej szkoły: monografia. Kraków. S. 33-40.

18. MUCHACKI M. BERNÁTOVÁ R. (2014). Professional competencies within the field of professional activity of teachers. História, súčasnost' a perspektívy vzdelávania na Pedagogickej fakulte Prešovskej univerzity $v$ Prešove: monografia. Prešov. S. 229-234.

19. OSTASZEWSKI K. (2014). Kompetencje zawodowe profilaktyka. Serwis informacyjny narkomania. Nr 4 (68). S. 8-13.

20. RATAJ M. (1972). Samokształcenie nauczycieli, Stan i potrzeby: monografia. Wrocław.

21. SARZAŁA D. JĘDRZEJKO M. Z. ZAWADZKI J. (2015). Wychowanie prospołeczne jako czynnik ograniczający powstawanie uzależnień behawioralnych. Uzależnienia behawioralne, Wybrane aspekty: monografia. Pułtusk-Warszawa 2015. S. 298-312.

22. SIUDEM I. (2010). Kompetencje zawodowe kadry a skuteczność programów profilaktycznych. Powinności i kompetencje w wychowaniu osób niedostosowanych społecznie: monografia. Lublin 2010. S. 81-92.

23. SOKOŁOWSKA-DZIOBA T. (2002). Umiejętności wychowawcze nauczycieli. Kształtowanie umiejętności wychowawczych: monografia. Lublin. S. 11-15.

24. ŚLIWERSKI B. (1993). Wyspy oporu edukacyjnego: monografia. Kraków.

25. TARASZKIWEICZ M. (2001). Jak uczyć się lepiej!: szkoła pełna ludzi: monografia. Poznań.

26. WASZCZUK J. (2014). Założenia efektywności szkolnych programów profilaktyki. Resocjalizacja Polska. Nr 6. S. 121-134.

27. WOJCIECHOWSKA M. SZPRINGER M. CHMIELEWSKI J. (2014). Samokształcenie nauczycieli we współczesnych uwarunkowaniach. Edukacja ustawiczna dorosłych. Nr 3 (86). S. 75-85.

\section{АНОТАЦІЯ}

Мета статті - показати важливість компетентності у профрілактичній роботі вчителя-вихователя.

У вступі були представлені категорії профресійної компетентності вчителів. В основній частині автор обговорює компетенції, якими повинні володіти вчитель-вихователь та вчитель-людина, яка займається профрілактикою.

Враховуючи припущення сучасної моделі профрілактики, де основними виконавиями є, в першу чергу, вчителі, автор показує, що компетентністю у галузі знань та вмінь повинен бути вчитель, який впроваджує шкільну програму профрілактики. Незважаючи на відсутність стандартизованих результатів навчання для вчителів у галузі профілактики, у статті пропонуються напрямки, в яких автор обгрунтовує свою думку щодо проходження вчителями підготовки.

Профрілактика, яка проводиться насамперед у школі, i одним із ї̈ завдань $\epsilon$ підтримка навчального процесу, повинна проводитись професіоналами, які також повинні мати знання та навички у галузі компетентності особистості, що схиляють їх до роботи з дітьми та молоддю.

Ключові слова: компетентність вчителів, профілактика компетентностей, профрілактика, шкільна програма профілактики 